\title{
The Corporate Response to the Fourth Industrial Revolution
}

\section{Peter Totterdill}

\begin{abstract}
From a critical perspective, Industry 4.0 risks being no more than the latest in the long line of technological predictions based on exaggerated claims. It risks drawing corporate decisionmakers into patterns of investment that ultimately fail, because they ignore the importance of synergy between the design and implementation of technologies on the one hand, and human and organisational factors on the other. There is a need to articulate the choices and alternative narrative surrounding Industry 4.0.

The technological advances represented by Industry 4.0 potentially offer real economic and also social benefits. At the same time, realising this potential, and avoiding the mistakes of the past, means recognising the importance of a new and more inclusive paradigm of innovation. The challenge is that of reconciling the ordered, rational organisation of work offered by emergent technologies with the creative, dialogical, serendipitous and even chaotic human interactions that can stimulate innovation.
\end{abstract}

Keywords: Competitiveness; determinism; digitalisation; employment, empowerment; Industry 4.0; innovation; quality of working life; skills; technology; workplace innovation. 


\section{A critical perspective}

When does a popular idea begin to outlive its usefulness, gradually obscuring the reality which it was intended to explain? How do we distinguish transient fashions in thinking and practice from underlying truths?

During my professional life I have seen (and sometimes contributed to) successive yet always short-lived fashions in predicting the future of work and the economy: Flexible Specialisation (Piore and Sabel 1984); the Virtual Organisation (Davidow \& Malone 1993); The End of Work (Rifkin 1995); the New Economy (1990s - ); Sociocracy and the Death of Hierarchy (e.g.: Endenberg 1998); the Millennial Workforce . . . and so on. 'The Fourth Industrial Revolution', more commonly known in Europe as 'Industry 4.0' since its adoption by the German Federal Government, is the latest in this long line of attempts to make sense of emerging forces in what is undoubtedly an increasingly volatile global economic environment.

In line with its predecessors in prediction, Industry 4.0 contributes important insights and enhances understanding of the challenges and opportunities facing corporations and policymakers alike. Yet claims that it offers a comprehensive, global narrative on the future of work and the economy, and indeed that it represents an inevitable as well as a desirable development, should be treated with caution. The concept is being driven "by computer scientists, engineers, innovation policy actors, influential business associations and larger technology-intensive enterprises" (Hirsch-Kreinsen 2014, p. 421), and as with other fads it contains much speculation, contradictory evidence and, most importantly, a tendency to conceal choices. As German researchers Kopp et al. (2017) argue, Industry 4.0 can easily become 'Technological Determinism 4.0', repeating the mistakes of previous eras in which technocratic reductionism became so pervasive in some industrial settings leading to expensive failure. Corporate and public discourse needs to recognise the existence of alternative narratives and competing choices.

Kopp et al. suggest that when the initial, still undiminished euphoria surrounding Industry 4.0 dies down, the choices and dilemmas which surround it will become much more evident. Indeed, economic and workplace futures in democratic societies will continue to be shaped by choices and decisions made by diverse stakeholders including politicians, scientists, thinkers and individuals rather than determined by a linear technological imperative.

In Europe, the public policy approach centres on raising the competitiveness of advanced manufacturing through enhanced innovative capacity, productivity, growth and employment, recognising the critical role of human factors and 'inclusive growth' (European Commission 2010). This article explores the corporate choices and opportunities involved in realising that goal.

The promise (and threat) of Industry 4.0 


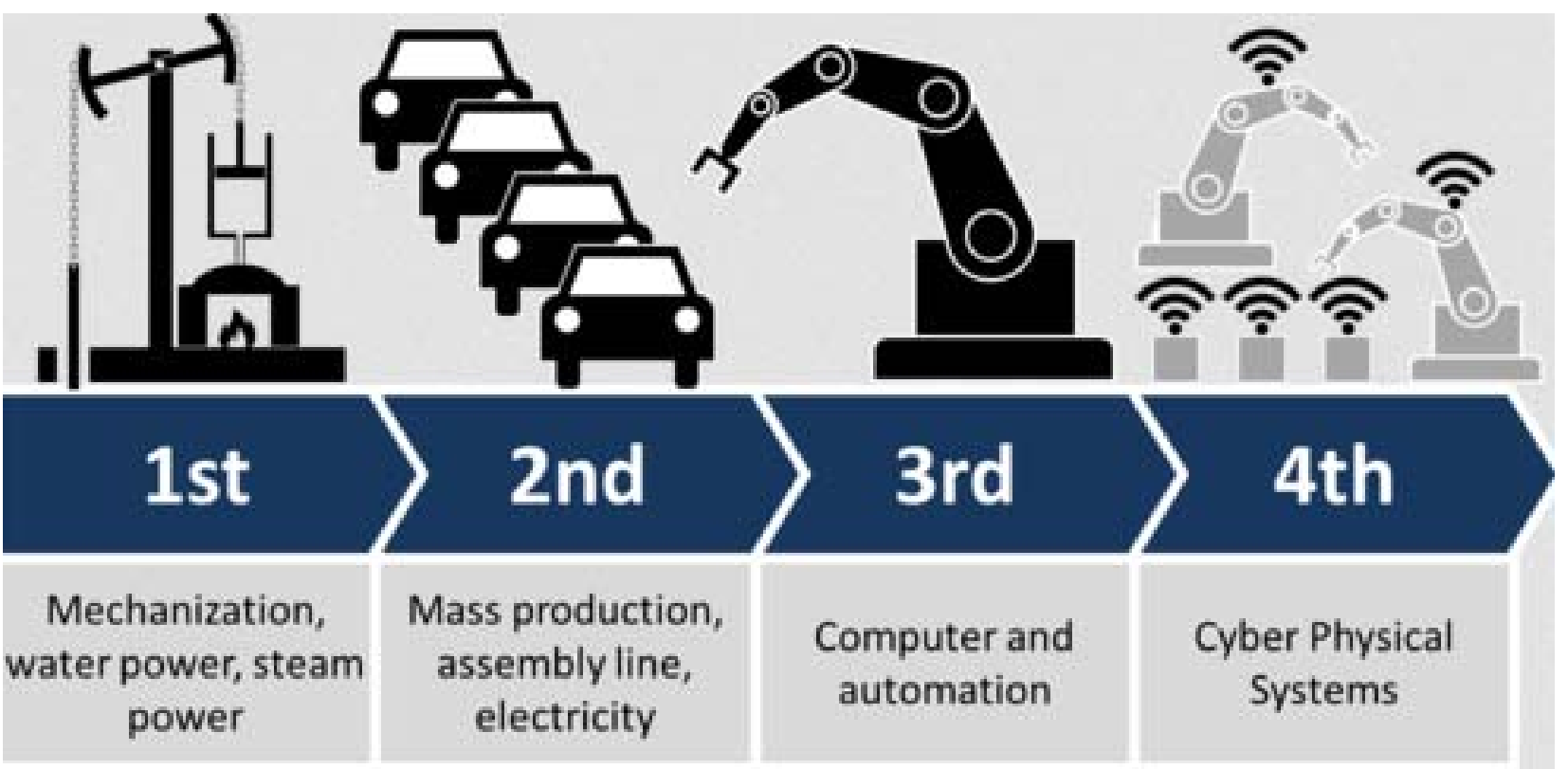

Figure 1: Industry 4.0. Source: Wikipedia

'Industry 4.0' describes a new level of organisation and management of the entire value chain across the product life-cycle, able to meet increasingly individualised customer wishes so that even one-off items can be manufactured profitably. It can form extended value creation chains linking manufacturers with their suppliers and customers, encompassing idea generation, product development, production, delivery to the end customer and eventually recycling.

The European Parliamentary Research Service (2015) summarises the new and innovative technological developments on which Industry 4.0 depends as follows:

- The application of information and communication technology (ICT) to digitise information and integrate systems at all stages of product creation and use (including logistics and supply), both inside companies and across company boundaries.

- Cyber-physical systems that use ICTs to monitor and control physical processes and systems.

- Network communications including wireless and internet technologies that link machines, work products, systems and people.

- Simulation, modelling and virtualisation in the design of products and the establishment of manufacturing processes.

- Collection of vast quantities of data, and their analysis and exploitation, either immediately on the factory floor, or through big data analysis and cloud computing.

- Greater ICT-based support for human workers, including robots, augmented reality and intelligent tools.

Transmission of data through the manufacturing chain, automation of production and the use of configurable robots lead to greatly enhanced flexibility and mass customisation since a variety of different products can be produced in small batches in the same facility. Such flexibility also encourages innovation, since prototypes or new products can be produced 
quickly without complicated retooling or setting up new production lines. Digital designs and virtual modelling of manufacturing process can reduce the time between product conception and delivery.

Customers will be able to be more involved in the design process. Production can also be located close to the customer because, if manufacturing is largely automated, it does not need to be 'offshored' or located in low labour cost countries, and 're-shoring' is already occurring in parts of Europe $^{4}$.

Integrating product development with digital and physical production has also been associated with large improvements in product quality and significantly reduced error rates since data from sensors can be used to monitor every piece produced rather than using sampling to detect errors, and error-correcting machinery can adjust production processes in real time.

Productivity can also increase. By using advanced analytics in predictive maintenance programmes, manufacturing companies can avoid machine failures on the factory floor and cut downtime significantly. Some companies are already setting up 'lights out' factories where automated robots continue production without light or heat after staff leave for home.

Industry 4.0 can also enable long-sought changes in business models. Rather than 'low road' competitive strategies based primarily on cost, Industry 4.0 may allow companies in high labour cost countries to compete on the basis of innovation, able to deliver new products rapidly to customer-driven designs with the assurance of high quality standards. Falling costs for digital technologies may also help to close the productivity gap between SMEs and large companies found in some European countries. Even more significantly, technologies such as 3D printing have the potential to decentralise the production of many consumer goods to local or even domestic sites, while current corporate manufacturers become pure software companies ${ }^{5}$.

Some argue $^{6}$ that, in addition, Industry 4.0 will address and solve social and environment challenges such as resource efficiency and demographic change. For example, workers can be released from routine tasks, enabling them to focus on creative, value added activities. Older workers will be able to extend working lives and remain productive for longer, ameliorating the impact of an ageing workforce in many European countries. Flexible work organisation should also enable workers to combine work, private lives and continuing professional development more effectively.

Yet these promises conceal considerable anxiety about how the transition to a better, brighter future will affect current jobs and businesses. Polarisation in European labour markets has been observed for some time (for example: Lundvall 1996). Low-skilled workers are offered few opportunities to upgrade their skills while those with higher education are offered more. The OECD Jobs Study (1994) showed that this process had already begun in the mid-1980s and it has continued ever since in Europe. Lundvall et al. (2008) found that growing income inequality excluded and marginalised low skilled workers from new employment opportunities. Arguably

\footnotetext{
${ }^{4}$ https://reshoring.eurofound.europa.eu/

$5_{\text {www.forbes.com/sites/ricksmith/2015/07/07/5-incredible-trends-that-will-shape-our-3d-printed- }}$ future/\#58799301fa48

${ }^{6}$ See for example www.workplaceinnovation.org/nl/kennis/kennisbank/industry-4-0/1241
} 
the consequences of this widening and cumulative process of marginalisation are reflected in growing political volatility represented by the election of President Trump in the USA, Brexit in the UK, and the rise of the far right in countries such as Germany, Hungary and Poland.

It is certainly clear that that greater use of digital industrial technologies will reduce the number of traditional assembly and production jobs, yet the scale of the loss is heavily contested. Based on a detailed analysis of several forecasts and projections, Bakhshi et al. (2017, pp.22-23) show that alarming and widely-publicised headline findings suggesting, for example, that " $47 \%$ of US workers' jobs are at high risk of automation" have been challenged by other researchers, and that once detailed task variations are taken into account the figure may be closer to $9 \%$. In the UK, they predict (p.13) that by 2030 "Around one-fifth (of employees) are in occupations that will likely shrink", and that these are mainly in low- or medium-skilled occupations in both manufacturing and administration. These projections are much lower than other recent studies of automation have suggested, reinforcing a view that in many occupations complete automation is not realistic and that improvements in productivity will be achieved mainly through enhancing human labour through digital assistance rather than replacing it ${ }^{7}$.

On the positive side, Gregory et al. (2016) estimate that automation boosted net labour demand across Europe by up to 11.6 million jobs over the period 1990-2010, as its job-destroying effects were offset by lower unit costs and prices which stimulate higher demand for products, and that surplus income from innovation was converted into additional spending, so generating demand for extra jobs in more automation resistant sectors.

Bakhshi et al. (2017, p.13) predict that in the UK "around one-tenth of the workforce are in occupations that are likely to grow as a percentage of the workforce" by 2030. Creative, digital, design and engineering occupations have bright outlooks and are strongly complemented by digital technology. They also cite US data which suggests that roles such as management analysts and training, development and labour relations specialists, all occupations associated with the reorganisation of work, are projected to grow. However, "roughly seven in ten people are currently in jobs where we simply cannot know for certain what will happen."

\section{Old skills for new jobs}

A common feature of projections about the employment impact of Industry 4.0 lies in the prediction that higher-order cognitive skills will feature prominently in the future demand for labour. Originality, fluency of ideas and active learning will be highly important as well as system thinking, judgement and decision-making skills, not just because they are necessary to manage complex technological systems but also because they feed the creativity required by a culture of innovation.

Social skills will also continue to grow in importance in building customer service and negotiating the co-ordination frameworks required by Industry 4.0 which will often involve the creation of high-trust relationships across the globe (Bakhshi et al. 2017; McKinsey 2017; PwC 2016). Strikingly, nearly all US job growth since 1980 has been in relatively social skill-

\footnotetext{
${ }^{7}$ See for example www.forbes.com/sites/haroldsirkin/2016/04/19/advanced-manufacturing-is-not-ajob-killer-its-a-job-creator/\#220cfa9d5ddd
} 
intensive occupations, and occupations with high analytical but low social skill requirements shrank over the same period (Deming 2015).

Bakhshi et al. (p.13) express optimism that "occupation redesign coupled with workforce retraining" could promote growth in occupations whose future is uncertain and enable the adaptation of workers whose jobs are under threat. Conceivably, digitally assisted work environments could ease the transition to new jobs and even encourage some older workers to return to work.

Lundvall's emphasis on the importance of 'discretionary learning jobs' is helpful in this context. Discretionary learning refers to a job situation where the employee has a certain freedom (discretion) to decide how to solve problems and where, in consequence, (s)he continuously learns new skills. It stands in contrast to Taylorist work where there is both little freedom to act and very limited learning for the employee. Arundel et al. (2007) found very clear patterns showing that in countries where ordinary workers are engaged in discretionary learning jobs, domestic enterprises were more engaged in radical innovation. Yet overall less than $40 \%$ of Europe's workers are employed in discretionary learning jobs (Lundvall 2014).

The challenge remains. Europe's track record in managing the transition of workers in declining industries to secure, skilled employment in other fields is at best patchy: and it is impossible not to think of the continuing marginalisation or exclusion of former coal miners, steel workers or sewing machinists in many communities. Active interventions to support workforce adjustment are certainly possible but this is no guarantee that this will happen, as Lundvall et al. (2008) found in their analysis of labour market polarisation discussed above.

\section{The emergence of a new innovation paradigm}

As we have seen, the Industry 4.0 narrative emphasises its potential to facilitate product and service innovation through digital design, virtual modelling and rapid prototyping. The key challenge is to understand the organisational conditions under which human creativity can realise this potential.

Innovation has often been seen as the prerogative of a scientific, entrepreneurial or management élite, yet recent research shows that it thrives in egalitarian learning economies where ordinary workers enjoy jobs that make full use of their skills and learning capacity (for example Lundvall et al., 2008). Likewise the traditional view of innovation has been challenged from several other complementary directions, for example "open innovation" (Chesbrough 2003), "customerdriven innovation" (Desouza et al. 2004), "co-creation" (Prahalad et al., 2004) and "networked innovation" (Valkokari et al. 2012) mirror important aspects of an emerging innovation paradigm that has to be considered alongside the technological dimensions of Industry 4.0. A tangible example can be found in the rise of 'FabLabs' and the 'Maker Movement' ${ }^{\prime}$. These have close links to 'free and open source' thinking including the open source software movement, sharing the philosophy that all can be empowered to use and shape creative technologies. They are being created by universities and colleges, by not-for-profit entities in local communities and, increasingly, by companies who want to supercharge innovation by forming spaces where

\footnotetext{
${ }^{8}$ See for example www.create-hub.com/comment/the-maker-movement-shifting-uk-manufacturing/
} 
frontline employees, customers and other stakeholders can think 'out of the box', collaborate and discover the potential for serendipitous breakthroughs.

Totterdill et al. (2016) argue that in the early 1990s a significant shift in Europe's economy could be observed, fuelled by information technology. This shift reversed the historical pattern in which tangible capital was considered the main asset in companies. From around 1990, investments in intangible capital (as a percentage of adjusted GNP) such as patents, R\&D, marketing and organisational competences became higher than investments in tangible capital (Corrado and Hulten 2010). The conviction grew in Europe that 'social innovation' in the workplace could be more important than 'technological innovation' in explaining company performance (Bolwijn et al. 1986). Developing and utilising the full range of skills and competences in the present and future workforce is therefore a vital component of competitive and knowledge-based global economy (European Commission 2014). Likewise the OECD Innovation Strategy, the culmination of a 3-year, multi-disciplinary and multi-stakeholder effort, emphasises that "empowering people to innovate" and "fostering innovative workplaces" is important for creativity, innovation and productivity (OECD 2010b). Moreover organisations only achieve a full return on investment in technological innovation if it is embedded in workplace innovation, in other words making the technology work by achieving a full synergy with human and organisational factors.

Jensen et al. (2007) used survey data from around 700 Danish firms to link their mode of learning to innovation performance, and the statistical analysis led to four clusters of firms: Low Learning, Science-Based Learning, Experience-Based Learning and a combination of Science- and Experience-Based Learning. Science-Based Learning refers to a process where systematic research plays a major role and the knowledge produced is often codified. Experience-Based Learning refers to learning by doing, learning by using and learning by interacting, and here much of the knowledge remains tacit, embodied in people and embedded in organisations.

Jensen et al. show that firms engaged in innovation need to combine the two modes. While firms that practised one of the two learning modes were twice as innovative as those with Low Learning, firms that combined the two modes were five times as innovative as those with Low Learning. Innovation management at corporate level therefore needs to focus on building a learning organisation and a pervasive culture of 'high involvement' and 'employee-driven' innovation (Tidd and Bessant 2009; Totterdill 2015).

\section{High involvement innovation and Industry 4.0}

To summarise the argument so far, the potential of Industry 4.0 will only be fully realised if the technocratic reductionism of previous eras is rejected and there is a reconciliation of what might be seen (Ennals et al., 2018) as two conflicting models: one focused on structure and order in order to attain the rational organisation of work, and the other in which creativity and human dialogue drive innovation: 


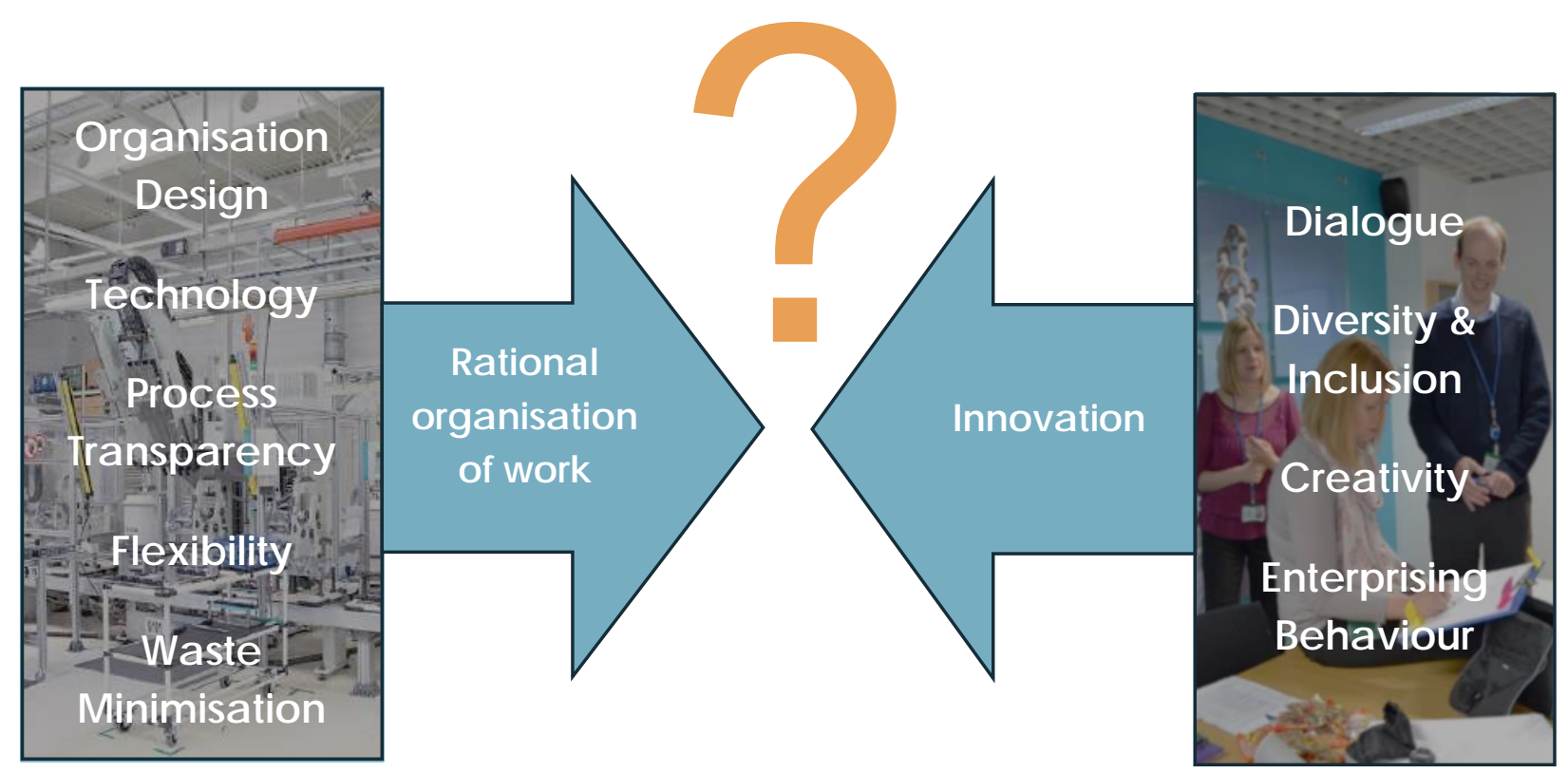

Figure 2: Structure and Order v. Dialogue and Creativity

In reconciling these two models, our starting point lies with the vast and growing body of evidence demonstrating that workplace practices which empower employees to contribute ideas and be heard at the most senior levels of an organisation lead to improved productivity and capacity for innovation, as well as enhanced workforce health and engagement (Pot 2011; Ramstad 2009; Totterdill 2015). Such practices have increasingly been described as 'workplace innovation' since the early years of the present century.

According to the Hi-Res study, a meta-analysis of 120 case studies across ten European countries, workplace innovation takes diverse forms but is always characterised by:

". . . a clear focus on those factors in the work environment which determine the extent to which employees can develop and use their competencies and creative potential to the fullest extent, thereby enhancing the company's capacity for innovation and competitiveness while enhancing quality of working life." (Totterdill et al. 2002).

Such factors in the work environment include empowering job design, self-organised teamworking, structured opportunities for reflection, learning and improvement, high involvement innovation practices, the encouragement of entrepreneurial behaviour at all levels of the organisation, and employee representation in strategic decision-making.

Workplace innovation is an inherently social process, creating self-sustaining processes of development by learning from diverse sources and by experimentation. It seeks to build bridges between the strategic knowledge of the leadership, the professional and tacit knowledge of frontline employees, and the organisational design knowledge of experts, engaging all stakeholders in dialogue in which the force of the better argument prevails (Pot et al. 2016; Gustavsen 1992).

Thus, in defining workplace innovation, it is important to recognise both process and outcomes. The term describes the participatory process of innovation which leads to outcomes in the form of participatory workplace practices. Such practices grounded in continuing reflection, learning 
and improvement sustain the process of innovation in management, work organisation and the deployment of technologies.

\section{Explaining workplace innovation}

Workplace innovation now occupies an important place in EU innovation and competitiveness policy, and led to the creation of the European Commission's Workplace Innovation Network ${ }^{9}$ (EUWIN) in 2012, jointly led by $\mathrm{TNO}^{10}$ and Workplace Innovation Europe ${ }^{11}$.

The creation of EUWIN provided an opportunity to address the need for a new type of dialogue between researchers and practitioners. EUWIN's task is to promote the dissemination of workplace innovation throughout Europe through knowledge sharing and dialogue ${ }^{12}$.

With limited resources, a clear framework for communication was a priority for EUWIN partners. Workplace innovation is a hard-to-grasp concept, and it was important to make it more communicable, without breaking the link with the large and complex body of research evidence that underpins it. This led to the formulation of The Fifth Element concept by the Workplace Innovation Europe team as a means of providing practical and actionable insights into evidence and experience underpinning workplace practices associated with high performance, innovation and quality of working life (Totterdill 2015).

The Fifth Element is based on an analysis of more than one hundred articles and a similar number of case studies from which four main bundles of workplace practices (or 'Elements') were detected, each associated with improved performance and quality of working life:

1. Jobs and Teams

2. Organisational Structures, Management and Procedures

3. Employee-Driven Improvement and Innovation

4. Co-Created Leadership and Employee Voice.

Each of these bundles does not exist in isolation but is influenced, for better or worse, by the others. Workplace innovation cannot be reduced to fragmented practices if it is to realise its potential. The literature emphasises the importance of internally consistent policies and practices combining different forms of representative and direct participation in achieving superior outcomes for organisations and their employees which are greater than the sum of individual measures (Lado and Wilson, 1994; Huselid, Jackson and Schuler 1997; Teague 2005). Likewise studies of failed workplace innovation emphasise the role of "partial change" in undermining the introduction of empowering working practices (Business Decisions Limited 2002). This provides the starting point for The Fifth Element.

Sustainable convergence between high performance and high quality of working life is explained by cumulative causation in which empowering workplace practices are aligned at

\footnotetext{
${ }^{9}$ http://ec.europa.eu/growth/industry/innovation/policy/workplace/index en.htm

10 www.tno.nl

11 www.workplaceinnovation.eu

12 http://uk.ukwon.eu/euwin-resources-new
} 
each level of the organisation. The mutually-reinforcing impact of workplace partnership, shared learning, high involvement innovation, enabling organisational structures and systems, self-organised teams and empowering job design can create a tangible effect in workplaces which is hard to quantify but which is often described in terms of "engagement" and "culture". By implication, the route to achieving high levels of employee engagement and a culture of innovation is not a direct one but must embrace the contents of each Element.

The Fifth Element has been adopted by EUWIN and subsequently by economic development agencies in the Basque Country, France and Scotland as a framework for raising awareness of workplace innovation and supporting its implementation.

\section{The Fifth Element in practice}

The metaphor of The Fifth Element is a useful way of capturing this essential quality, describing an alchemic transformation that can only take place when the other four elements combine. The concept is explained further on the EUWIN Knowledge Bank and in a short film ${ }^{13}$.

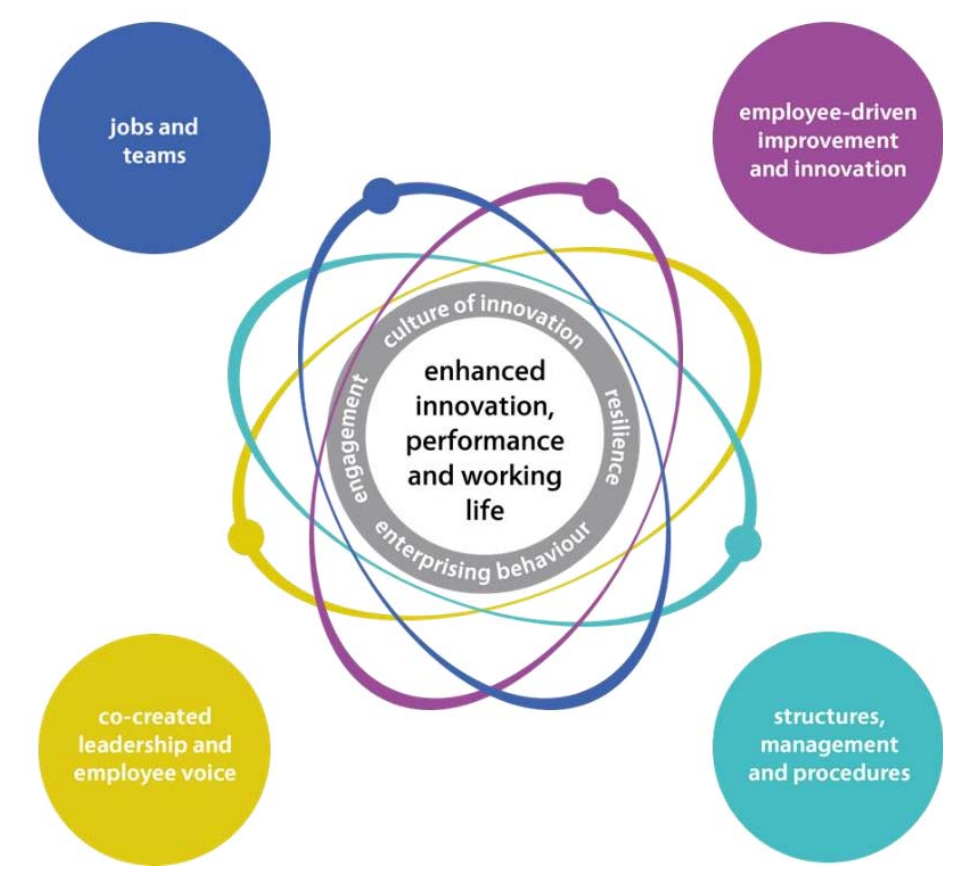

Figure 3: The Fifth Element: conceptualising the characteristics and outcomes of workplace innovation

\section{The First Element: Jobs and Teams}

Building workplaces in which employees can develop and deploy their competencies and creative potential begins with job design. Well-designed jobs that provide constructive challenges, opportunities for day-to-day problem solving, variety and collaboration help people manage the demands placed on them and avoid the psychological stress and disengagement associated with repetitive and disempowering work (Bakker and Demerouti 2007; Morgeson and Humphrey 2006; Shantz et al. 2013; Truss et al. 2013). Moreover through exercising

13

http://uk.ukwon.eu/the-fifth-element-new 
discretion in such "complex jobs" employees acquire skills that are transferable, increasing their adaptability and resilience within the organisation and their employability outside it, even in quite different occupations (CEDEFOP 2015).

In De Sitter's STSD theory the central idea is the balance between 'control requirements' (quantitative and qualitative demands) and 'control capacity' (job control). "It's not the problems and disturbances in the work that cause stress, but the hindrances to solve them" (De Sitter 1981, p.155). In order to maintain this balance, control capacity is required regarding the performance of a given job on individual job level as well as regarding the division of labour on production group and plant level: "from complex organisations with simple jobs to simple organisations with complex jobs" (De Sitter et al. 1997). Besides internal control capacity, complex jobs also include participation in external control activities at production group and plant level (for example shop floor consultation on processes, division of labour and targets). The aim of such sociotechnical design is to simultaneously result in improved organisational performance, quality of working life and better labour relations.

De Sitter (1981) integrated the 'job demands-control-model' (Karasek 1979) in his theory. The job demands-control (JDC) model holds two predictions. High job demand and low job control separately represent risk factors that are detrimental to (mental) health outcomes such as work stress and coronary heart disease. The model also predicts that high job demand, as well as high job control fosters motivation and learning. The most commonly used definition of job control (or decision latitude): which describes the features of jobs and not of individual job performers, is primarily the ability of the worker to use his or her skills on the job and to have authority to make decisions regarding how the work is done, and to set the schedule for completing work activities. Central features of the JDC model are also the strain and learning hypotheses, referring to two interaction hypotheses on the balance between job demands and job control. Jobs with high demands and low control can be called 'high strain jobs' which are a risk for work-related stress. Moreover, stress inhibits learning. But jobs with high demands as well as high control are called 'active jobs' which offer opportunities for learning and coping with stressors (Karasek 1979; Karasek and Theorell 1990). Later, this JDC model was extended with the social support dimension (support of colleagues and supervisor) and with innovative and productive work behaviour (Karasek and Theorell 1990). Empirical evidence for the JDC model can be found in De Lange et al. 2003, 2005; Taris et al. 2003; Häusser et al. 2010; Demerouti et al. 2001; Taris et al. 2003; Lyness et al.2012; Stansfeld et al. 2013; Gallie 2013; Dhondt et al. 2014.

Effective job design must develop in synchrony with the wider organisational context. The key concept here is teamworking, one of the defining characteristics of workplace innovation, with deep roots in European thinking about management and organisation dating back to the work of the Tavistock Institute in the 1940s and 50s. Extensive research demonstrates that empowered and self-managed teams are more productive in factories and offices, provide better customer service, and even save lives in places like hospitals (Totterdill et al. 2002; West 2012; European Foundation for the Improvement of Living and Working Conditions 1997).

However 'teamwork' is increasingly used to describe such a diverse range of workplace situations that arguably the term is in danger of becoming meaningless. While teamworking may refer to a general 'sense of community', or a limited enlargement of jobs to enhance 
organisational flexibility, empowered teamworking will involve a radical re-appraisal of jobs, systems and procedures throughout the whole organisation (West and Lyubovnikova 2012).

'Real' teams are more than groups of co-located employees; they share knowledge and problems, break down barriers and demarcations, and generate ideas for improvement, innovation and growth using the insight that day-to-day work experiences give them. All team members must have the potential for a high level of reflexivity unconstrained by internal demarcations and privileges (Gustavsen 1992).

Teams in which the specific knowledge and expertise of each team member are valued and make a tangible contribution to product and workplace innovation meet important criteria for convergence between enhanced productivity and enhanced quality of working life. Yet convergence is only possible and sustainable when structures, systems, industrial relations and leadership are fully aligned with the empowerment of employees in their day-to-day jobs (Boxall and Purcell 2003; Buchanan and Preston 1992; Teague 2005), hence the interdependence with the Second, Third and Fourth Elements.

\section{The Second Element: Organisational Structures, Management and Procedures}

The Fifth Element approach recognises the need for a consistent approach to empowerment, learning and development running through every aspect of corporate policy from reward systems and performance appraisal to flexible working and budget devolution.

Hierarchical management layers inevitably put distance between decision-making and the frontline, disempowering and diminishing the voice of those at the lower levels as well as creating an implementation gap. Hierarchy breeds caution amongst managers, encouraging decisions to be delegated upwards with consequent loss of productivity and responsiveness. Such vertically organised structures create silos and add to the difficulties of building bridges between functional specialisms. This often causes frustration in resolving day-to-day issues and can have a particularly negative effect on the capacity for innovation (Mumford 2006). Flexible and decentralised structures and systems that are consistent and fair are required to eliminate feelings of disbelief and mistrust, to reduce management distance and to create a culture conducive to innovation (Judge et al. 1997; Martins 2000; Saunders \& Thornhill 2003).

Flat organisations rely on a decentralised approach to management and require a high degree of employee involvement in decision-making (Ghiselli et al. 1972). Control in flat companies lies in mutual agreements between self-managing, self-organising and self-designing teams and employees who take personal responsibility for satisfactory outcomes. This in turn empowers employees, facilitates information sharing, breaks down divisions between roles, shares competencies, and uses team or organisation-wide reward systems.

Yet even within more flexible structures, mistrust and disempowerment can be embedded in the systems and processes that shape decision-making, resource allocation, standard operating procedures and performance management. They can reflect a culture of centralised control and micro-management which requires careful dismantling.

For example, managing performance is often reduced to a necessary but poorly understood ritual. Line managers go through the motions of annual appraisals to demonstrate compliance with established procedures but there is little evidence of a strong impact on motivation, 
personal and team development, or the removal of obstacles to high performance. Employees themselves often approach performance discussions either with indifference or with the anxiety that some aspect of underperformance may be sprung upon them. Yet effective coaching for high performance can produce continuous and sustainable improvements. In such cases managers recognise performance coaching as a valuable resource in their overall approach as team leaders.

\section{The Third Element: Employee-Driven Innovation and Improvement}

Studies of innovation in complex organisations emphasise the importance of large numbers of people empowered to act in entrepreneurial ways in pursuit of shared goals (Buchanan 2006; Høyrup et al. 2012).

Good and sustainable organisations build a set of internal reflexive mechanisms. Systematic opportunities for shared learning and 'productive reflection' (Boud et al. 2006) are well embedded in these workplaces. This is reflected in times and spaces where people at work can discuss ideas with co-workers or in team meetings. It can be as simple as establishing regular forums that enable people at all levels of an organisation to leave job titles and hierarchies behind, and to explore new ideas through open and free-thinking discussion.

Such organisations provide employees with regular opportunities to join cross-functional teams to identify and drive forward product or process changes that would otherwise be lost under the pressure of day-to-day workloads, and such practices appear in recommendations for the successful implementation of Industry 4.0 (for example PwC 2016). Time-out sessions, 'downtools weeks' and hackathons, bringing people together who otherwise wouldn't meet, can become fountains of constructive dialogue, creativity and innovation ${ }^{14}$. These companies recognise the importance of experimentation and 'fast failure' as sources of shared learning, removing 'blame cultures' when things go wrong.

For an increasing number of organisations it means creating dedicated innovation spaces or 'FabLabs' that bring diverse combinations of people together, thinking in different ways, sharing technical knowledge and insights, creating new products or services and reinventing work processes. Increasingly the importance of the physical workplace may lie more in its ability to support serendipitous contact, congeniality, emotional engagement and the sharing of tacit knowledge, than to support the delivery of routine tasks. This is already being reflected in contemporary office design.

Ideas for improving the business should also be part of the day job. Many companies argue strongly that new ideas can come from anyone and reject the idea of setting up a separate innovation team. Networks of volunteer 'guerrillas', recruited from every level of the organisation, trained in facilitation techniques and empowered to ask difficult questions, can be used to establish a culture of innovation ${ }^{15}$.

Tidd and Bessant (2009) argue that such examples of high involvement innovation must reflect deeper structural practices within each organisation: sustainable and effective employee

\footnotetext{
14 http://uk.ukwon.eu/learning-reflection-and-innovation-new

15 See for example http://uk.ukwon.eu/met-office
} 
engagement cannot happen in isolation but must be driven from the top and reinforced by empowerment and autonomy in day-to-day working.

\section{The Fourth Element: Co-Created Leadership and Employee Voice}

Leadership theory is a highly contested field but leadership development has nonetheless gained increasing prominence through business school curricula, professional institutions and consultant offerings. Early theories were primarily focused on the distinction between "task focus" and "people orientation" (for example Vroom and Yetton 1988) but the emergence of "New Leadership Theories" led to the celebration of "transformational", "charismatic", "visionary" and "inspirational" leadership (Storey and Holti 2013), often drawing on the burgeoning hagiographies of business leaders such as Jack Welch and Steve Jobs.

The dark side of such leadership approaches soon began to emerge including the potential for abuse of power, narcissism, destabilisation, blind obedience and fear of questioning. It can even be argued that the extraordinary trust in the power of charismatic CEOs displayed in these leadership approaches "resembles less a mature faith than it does a belief in magic" (Khurana 2002).

Alternative approaches focused on leadership as a creative and collective process (Senge, 1990) were less concerned with the central, charismatic individual and more with the creation of opportunities for employees to seize the initiative and contribute to decision making. Such "shared and distributed leadership" relates to a concern with empowerment (Caldwell 2005) and "change agency", a phenomenon characterised by dispersed responsibility for change and not to be confused with the more heroic or charismatic models of "change leadership" (Buchanan et al. 2007). For Gronn (2002) the principle advantage of distributed leadership is that it builds organisational capability, and is therefore a key element of workplace innovation in that it helps to release the full range of employee knowledge, skills, experience and creativity (Totterdill 2015).

Leadership is therefore a collaborative, or Co-Created process. It is not dependent on individual charisma or authority but creates shared direction and purpose through organisation-wide opportunities for strategic thinking, shared reflection and learning, and employee voice in decision-making. Employee Voice describes the alignment of strategic priorities and decisionmaking at senior levels with the practical knowledge, experience and engagement of employees throughout the organisation. It brings together direct participation through, for example, selfmanaged teams and improvement groups, with representative participation in the form of employee or union-management partnership forums.

Representative participation, or workplace partnership between management, employees and/or trade unions is an important aspect of this process of co-creation. At its most basic level partnership agreements and structures are a way of dealing proactively with industrial relations issues, ensuring early consultation on pay and conditions, employment changes and organisational restructuring. Employers pursuing high-performance, high-involvement practices are particularly "likely to be impatient with traditional adversarial approaches to collective representation" (Kessler and Purcell 1995).

Partnership between management, employees and trade unions can take many forms, but always requires openness, transparency and two-way communication. Nobel-prize winner Akerlof 
(1982) contends from an economic perspective that participation needs to take the form of giftexchange or reciprocity to be effective. Gustavsen (1992) emphasises the need for democratic relations to optimise the outcomes for management and employees alike. At the very least it can be an effective tool for positive industrial relations, minimising conflict and resistance to change.

An important body of research has begun to show that representative partnership structures (such as works councils and management-union partnership forums) on their own may have little direct impact on performance or quality of working life. Rather they can exert a positive influence on the development of activities and practices that do so. Representative partnership creates opportunities for employees to exercise greater autonomy and direct participation (Batt and Appelbaum 1995). Workplace partnership thus moves away from its traditional focus on industrial relations, emerging as a potentially important driver of, and resource for, organisational innovation in the broadest sense (Huzzard et al. 2005; Cressey et al. 2013).

When partnership arrangements exist alongside the types of participative workplace practices described in the previous three Elements it creates a system of mutually reinforcing practices leading to improved information sharing, greater levels of trust, reduced resistance to change and heightened performance. This combination of representative and direct involvement is known as "employee voice" (Boxall and Purcell 2003).

\section{The Alchemy of The Fifth Element}

The Fifth Element highlights the importance of understanding the interdependence between the workplace practices described in each of the four Elements. There is sufficient research to demonstrate that each bundle of practices described above does not exist in isolation but is influenced, for better or worse, by the extent to which the values and goals that underpin it are supported by those of the others.

The Fifth Element can be related to the 'configurational approach of strategic human resource management' (SHRM): "In general, configurational theories are concerned with how the pattern of multiple independent variables is related to a dependent variable rather than with how individual independent variables are related to the dependent variable" (Delery and Doty 1996, p.804). Thus, bundles of practices are more effective than separate interventions (Sheehan 2013).

Undoubtedly the nature of this interdependence requires further research, but the coming together of knowledge and experience from diverse researchers and practitioners within the framework of The Fifth Element is providing a rich resource for such work.

\section{Conclusion}

Industry 4.0 must be approached from a critical perspective, not least because of the hype and exaggeration which surrounds its claims and potential impact. Drawing on past history, there are real dangers that a technocratic-driven narrative will draw corporate decision-makers into reductionist models and patterns of investment that ultimately fail, because they ignore the importance of synergy between the design and implementation of technologies and human and organisational factors. 
This paper has discussed two separate narratives: the first focused on the ordered, rational organisation of work offered by emergent technologies; the second on the creative, dialogical, serendipitous and even chaotic human interactions that can stimulate innovation. Reconciling these narratives is essential if past mistakes are to be avoided and the positive potential of Industry 4.0 is to be realised.

The concept of Workplace Innovation, predating Industry 4.0 by a decade or so, prefigures many of its attributes. Like Industry 4.0, Workplace Innovation also seeks a transition between business models focused on cost-based competition to those based on innovation. It seeks the removal of monotonous work and its replacement with jobs focused on analysis, problemsolving, judgement, social interaction and creativity.

Learning from companies that have broken the mould will play a vital role in understanding the choices available to corporate decision-makers. The EUWIN Knowledge Bank ${ }^{16}$ contains inspiring cases of new-generation companies in sector as diverse as IT, food production and pharmaceuticals that demonstrate the competitive importance of flat organisational structures, self-managed teams and co-created leadership, offering clear signposts to the future. Equally it provides evidence that long-established companies can change in radical ways through journeys of experimentation and learning.

Blending the ordered rationality of engineering and technology with the empowering and creative practices associated with workplace innovation will not be easy, and certainly challenges established cultures in many large corporate organisations. From our own experience of working with engineers and scientists, as well as leaders in advanced technology companies, resistance to change is a powerful force even where the business case is clear.

Predictably many corporate decision-makers will choose what they perceive to be safe, technocratic routes which leave existing top-down or paternalistic cultures and working practices intact. Yet such risk-averse strategies ignore the lessons of previous eras, and indeed those of recent economic crises which show that survival is not compulsory even for the largest players.

\author{
About the author \\ Dr Peter Totterdill \\ Director, Workplace Innovation Europe \\ Visiting Professor, Kingston University London and Mykolas Romeris University Vilnius \\ Email: peter.totterdill@workplaceinnovation.eu
}

16 http://uk.ukwon.eu/euwin-knowledge-bank-menu-new 


\section{References}

Alvesson M. \& Willmott H. (2002) "Identity Regulation as Organizational Control: Producing the Appropriate Individual”. Journal of Management Studies, Vol. 39, No. 5, 619-44.

Antila J. \& Ylöstalo P. (1999), Functional Flexibility and Workplace Success in Finland, Ministry of Labour, Helsinki.

Appelbaum E., Bailey T., Berg P., Kalleberg A.L. (2000), Manufacturing Advantage: Why High-Performance Work Sysems Pay Off. Ithaca, NY: ILR Press.

Appelbaum E., Gittell J. H. \& Lean, C. (2010), High-performance work practices and sustainable economic growth. Washington: CEPR, Centre for Economic Policy Research.

Arundel A., Lorenz E, Lundval, B.-Å. \& Valeyre, A. (2007), "How Europe's economies learn: a comparison of work organization and innovation mode for the EU-15", Industrial and Corporate Change, 16 (6), 1175-210.

Bakhshi H., Downing J., Osborne M. \& Schneider P. (2017), The Future of Skills: Employment in 2030. London: Pearson and Nesta.

Barney J. (1995), "Looking inside for competitive advantage". Academy of Management Executive. Vol. 9, no. 4. Borrill C., Carlette T., Carter A., Dawson J., Garrod S., Rees A., Richard, A., Shapiro D., West M., (2001) The Effectiveness of Health Care Teams in the National Health Service. Aston University, University of Glasgow, University of Leeds, UK.

Bolwijn P.T., van Breukelen Q.H., Brinkman S. \& Kumpe T. (1986), Flexible Manufacturing: Integrating Technological and Social Innovation, Elsevier, Amsterdam.

Boxall P. \& Purcell, J. (2003), Strategy and Human Resource Management. Palgrave Macmillan, Basingstoke.

Buchanan D., Addicott R., Fitzgerald L., Ferlie E. \& Baeza J. (2007) "Nobody in charge: distributed change agency in healthcare. Human Relations, July, 60: 1065-1090.

Buchanan D. A. \& Dawson P., (2007), Discourse and audience: Organizational change as a multi-storey process". Journal of Management Studies, 44 (5) 669-686.

Buchanan D. A. \& Preston D. (1992), "Life in the cell: supervision and teamwork in a "manufacturing systems engineering" environment". Human Resource Management Journal, 2 (4) 55-80.

Business Decisions Ltd (2002), New forms of work organisation: the obstacles to wider diffusion. KE-47-02-115- EN-C, DG Employment and Social Affairs, European Commission, Brussels.

Caldwell R. (2005), Agency and Change: Rethinking Change Agency in Organizations. Abingdon: Routledge.

CEDEFOP (2015), Matching skills and jobs in Europe: Insights from Cedefop's European skills and jobs survey. http://www.cedefop.europa.eu/en/publications-andresources/publications/8088 (accessed 03.09.2017). 
Chesbrough H.W. (2003), Open Innovation: The New Imperative for Creating and Profiting from Technology. Boston.

Collinson D. L. (2003), "Identities and Insecurities: Selves at Work", Organization, Vol. 10, No. 3, 527-47.

Corrado C. \& Hulten C. (2010), "How do you measure a technological revolution?" American Economic Review, Vol. 100, No 5, pp.99-104.

Cressey P., Exton R., Totterdill P., (2013), "Workplace Social Dialogue as a Form of 'Productive Reflection'”, International Journal of Action Research, Vol. 9, Issue 2, pp 209 245.

Davidow W. \& Malone M. (1993), The Virtual Corporation: Structuring and Revitalizing the Corporation for the 21st Century New York: Harper.

De Lange A.H., Taris T.W., Kompier M.A.J., Houtman I.L.D. \& Bongers,P.M. (2003), "The very best of the millennium: longitudinal research and the demand-control-(support) model". Journal of Occupational Health Psychology, Vol. 8, No. 4, pp.282-305.

De Lange A.H., Taris T.W., Kompier M.A.J., Houtman I.L.D. \& Bongers P.M. (2005), "Different mechanisms to explain the reversed effects of mental health on work characteristics". Scandinavian Journal of Work, Environment and Health, Vol. 31, No. 5, pp.314.

De Sitter L.U. (1981), Op weg naar nieuwe fabrieken en kantoren (Translated: Heading for New Factories and Offices). Kluwer: Deventer.

De Sitter, L.U. (1994), Synergetisch produceren. Human Resources Mobilisation in de produktie: een inleiding in de structuurbouw, Van Gorcum, Assen.

De Sitter L.U., den Hertog J.F. \& Dankbaar B. (1997), "From complex organizations with simple jobs to simple organizations with complex jobs." Human Relations, Vol. 50, No. 5, pp.497-534.

Delery J. E. and Doty D. H., (1996), "Modes of Theorizing in Strategic Human Resource Management: Tests of Universalistic, Contingency and Configurational Performance Predictions". Academy of Management Journal, 39 (4): 802-35.

Deming D., (2015), The growing importance of social skills in the labor market. Tech. Rep. 21473, NBER Working Paper.

Demerouti E., Bakker A.B., Nachreiner F. \& Schaufeli W.B. (2001), "The job demands-resources model of burnout". Journal of Applied Psychology, Vol. 86, No. 3, pp.499512 .

Desouza K. C. \& Awazu Y. (2004), "Gaining a Competitive Edge from Your Customers: Exploring the Three Dimensions of Customer Knowledge". KM Review 7(3), pp. 12-15.

Dhondt S., Pot F. \& Kraan K. (2014), "The importance of organizational level decision latitude for wellbeing and organizational commitment". Team Performance Management: An International Journal, Vol. 20, Nos. 7/8, pp.307-327. 
Docherty P., Kira M., Shani A.B. eds. (2009), Creating Sustainable Work Systems: Developing Social Sustainability. Abingdon: Routledge.

Endenburg G. (1998), Sociocracy: The organization of decision-making. Eburon, The Netherlands.

Ennals R., Holtskog H., Berge M., Midtbø I. L. \& Garmann Johnsen H. C. (2018), ”Coping with Organisations: Sociotechnical, Dialogical and Beyond". In Garmann Johnsen H. C., Holtsko, H. \& Ennals R. Coping with the Future. Rethinking Assumptions for Society, Business and Work. London: Routledge.

Eurofound (2012), 5th European Working Conditions Survey. Overview report. Dublin: Eurofound.

European Commission (2010), EUROPE 2020 A strategy for smart, sustainable and inclusive growth. $\mathrm{COM}(2010) 2020$ Brussels, 3.3.2010.

European Commission (2014), Advancing Manufacturing - Advancing Europe - Report of the Task Force on Advanced Manufacturing for Clean Production, SWD (2014) 120 final, Commission staff working document, Brussels.

European Parliamentary Research Service (2015), Industry 4.0: Digitalisation for productivity and growth. www.europarl.europa.eu/thinktank/en/document.html?reference=EPRS BRI\%282015\%2956 $\underline{8337}$ (accessed 06.10.2017).

Exton R., (2010), "Enterprising health: Creating the conditions for entrepreneurial behaviour as a strategy for effective and sustainable change in health services", Journal of Health Organization and Management, Vol. 24, Iss: 5, pp.459 - 479.

Fricke W. (1997), "Evaluation of the German work and technology programme from an action research point of view" In Alasoini T., Kyllönen M. \& Kasvio A. (Eds) Workplace innovation: a way of promoting competitiveness, welfare and employment, National Workplace Development Programme, Helsinki.

Fricke W. \& Totterdill P. (2004), Action Research in Workplace Innovation and Regional Development, John Benjamins, Amsterdam.

Fricke W. (1983), "Participatory research and the enhancement of workers' innovative qualifications". Journal of Occupational Behaviour Vol. 4, 73-87.

Gallie D. (2013), Direct participation and the quality of work, Human Relations, Vol. 66, No. 4, pp.453-473.

Ghiselli E. \& Siegel J.P., (1972), "Leadership and Managerial Success in Tall and Flat Organization Structures". Personnel Psychology 25 (4): 617.

Gregory T., Salomons, A., Zierahn, U., (2016), "Racing with or against the machine? Evidence from Europe.” Tech. Rep. 16-053.

Gregory D., Huzzard T., \& Scott R. (2005), Strategic Unionism and Partnership: Boxing or Dancing? Houndmills: Palgrave MacMillan. 
Gronn P. (2002), "Distributed leadership as a unit of analysis.” Leadership Quarterly, 13, 42351.

Gustavsen B. (1992), Dialogue and Development, Van Gorcum: Assen/Maastricht.

Gustavsen B. (2004), "Participation and local organisation", in Fricke W. \& Totterdill P., Action Research in Workplace Innovation and Regional Development, John Benjamins, Amsterdam.

Hardy C. \& Leiba-O'Sullivan S. (1998), “The Power Behind Empowerment: Implications for Research and Practice”. Human Relations, 1998 51: 451.

Hirsch-Kreinsen H. (2014), Wandel von Produktionsarbeit - Industrie 4.0. In: WSI Mitteilungen 6/2014.

Holm J.R., Lorenz E., Lundvall B.-Å. \& Valeyre A. (2010), “Organisational learning and systems of labour market regulation in Europe," Industrial and Corporate Change, 19 (4), $1141-73$.

Høyrup S., Bonnafous-Boucher M., Hasse C., Lot, M. \& Møller K. eds. (2012), EmployeeDriven Innovation: A New Approach, Palgrave Macmillan, London.

Howaldt H., Kopp R. \& Flocken P. eds. (2001), Kooperationsverbünde und regionale Modernisierung - Theorie und Praxis der Netzwerkarbeit. Wiesbaden, Germany.

Huselid M.A., Jackson S.E. \& Schuler R.S. (1997), “Technical and strategic human resource management effectiveness as determinants of firm performance," Academy of Management Journal, Vol.40 No.1, pp.171-188.

Jacobsen H. (2005), "Produktion und Konsumtion von Dienstleistungen: Konsumenten zwischen Innovation und Rationalisierung.” In: Jacobsen H. \& Voswinkel S. (eds.): Der Kunde in der Dienstleistungsbeziehung. Wiesbaden, pp. 15-36.

Jensen M.B., Johnson B., Lorenz E. \& Lundvall B-Å. (2007)," Forms of knowledge and modes of innovation", Research Policy, 36 (5), 680-93.

Judge W. Q., Fryxell G., \& Dooley R. (2000), The new task of R\&D management: creating goal directed communities for innovation. In Lesser E, Fontain M., \& Slusher J., Knowledge and Communities. US: Butterworth-Heinemann.

Lay G., Dreher C. \& Kinkel S. (1996), "Neue Produktionskonzepte leisten einen Beitrag zur Sicherung des Standorts Deutschland”. ISI Produktionsinnovationserhebung Nr. 1, FraunhoferInstitut für System- und Innovationsforschung (ISI), Karlsruhe, Germany.

Lundvall B.-Å. (1996), The Social Dimension of the Learning Economy, Aalborg, DRUID Working Paper No. 96-1.

Lundvall B-Å. (2014), “Deteriorating quality of work undermines Europe's innovation systems and the welfare of Europe's workers!” EUWIN Bulletin, June.

Lundvall B.-Å. (2016), The Learning Economy and the Economics of Hope. London, Anthem Press. 
Lundvall, B.-Å. \& Johnson, B. (1994), "The learning economy", Journal of Industry Studies, Vol. 1, No. 2, December 1994, pp. 23-42.

Lundvall B-Å. and Nielsen P. (2007), "Knowledge management and innovation performance”, International Journal of Manpower, 28 (3-4), 207-23.

Lundvall B-Å., Rasmussen P. \& Lorenz E. (2008), "Education in the learning economy: a European perspective", Policy Futures in Education, 6 (2), 681-700.

Lyness K.S., Gornick J.C., Stone P. \& Grotto A.R. (2012), "It's all about control: worker control over schedule and hours in cross-national context", American Sociological Review, Vol. 77, No. 6, pp.1023-1049.

Martins E., \& Terblanche F. (2003), "Building organisational culture that stimulates creativity and innovation". European Journal of Innovation Management, 6(1), 64 -74.

McKinsey Global Institute. (2017), A future that works: Automation, employment and productivity. Available at www.mckinsey.com/global-themes/digital-disruption/harnessingautomation-for-a-future-that-works (accessed 09.10.2017).

PwC. (2016), Industry 4.0: Building the digital enterprise: www.pwc.com/gx/en/industries/industry-4.0.html (accessed 09.10.2017).

OECD (1994), The OECD Jobs Study. Paris: OECD.

OECD (2010), Innovative Workplaces: Making Better Use of Skills within Organisations. Paris: OECD Publishing.

OECD (2010b), The OECD innovation strategy: Getting a head start on tomorrow. Paris: OECD Publishing.

Osterman P. (1994), "How common is workplace transformation and who adopts it?" Industrial and Labor Relations Review, January.

Pass S. (2008), Working in partnership: What does the academic research tell us? London: Department of Health.

Pettigrew A.M. (1987) "Context and Action in the Transformation of the Firm". Journal of Management Studies, 24 (6), 649-670.

Pot F.D. (2011), "Workplace Innovation for better jobs and performance". International Journal of Productivity and Performance Management, 60 (4), 404-415.

Pot F., Dhondt S. \& Oeij P. (2012), "Social innovation of work and employment". In Franz HW, HochgernerJ. \& Howaldt J. (Eds.), Challenge Social Innovation. Potential for business, social entrepreneurship, welfare and civil society. Berlin: Springer, 261-274.

Pot F., Totterdill P. \& Dhondt S. (2016), "Workplace innovation: European policy and theoretical foundation". World Review of Entrepreneurship, Management and Sustainable Development, 12 (1), 13-32.

Prahalad C.K. \& Ramaswam, V. (2004), “Co-Creation Experiences: The Next Practice in Value Creation." Journal of Interactive Marketing, Volume 18, Number 3. 
Priem R. \& Butler J. (2001), "Is the resource-based 'view' a useful perspective for strategic management research?” The Academy of Management Review, Vol. 26, No. 1, pp 22-40.

Ramstad E. (2009), "Promoting performance and the quality of working life simultaneously". International Journal of Productivity and Performance Management, 58 (5), 423-436.

Saunders M. N., \& Thornhill A. (2003), "Organisational justice, trust and the management of change: An exploration”. Personnel Review, 32(3), 360 - 375.

Shortell S. M., Zimmerman J. E., Rousseau D. M., Gillies R. R., Wagner D. P. \& Draper E. A., (1994), "The performance of intensive care units: Does good management make a difference?" Medical Care 32(5) 508-525, American Public Health Association, Lippincott, Williams and Wilkins, PA, USA.

Stansfeld S.A., Shipley M.J., Head J., Fuhrer R. \& Kivimäki M. (2013), "Work characteristics and personal social support as determinants of subjective well-bein"g, PLoS ONE, Vol. 8, No. 11 .

Storey J. \& Holti R. (2013), Towards a New Model of Leadership for the NHS. London: NHS Leadership Academy.

Taris T.W., Kompier M.J., De Lange A.H., Schaufeli W.B. and Schreurs P.J.G. (2003), "Learning new behaviour: a longitudinal test of Karasek's active learning hypothesis among Dutch teachers", Work \& Stress, Vol. 17, No. 1, pp.1-20.

Teague P. (2005), "What is Enterprise Partnership?” Organization, 12:567.

Tidd J. \& Bessant J., (2009), Managing Innovation: Integrating Technological, Market and Organizational Change, 4th edition, Chichester: John Wiley and Sons.

Totterdill P., Cressey P. \& Exton R. (2012),’Social innovation at work: workplace innovation as a social process". In: Franz H-W, Hochgerner J., Howaldt J. (eds) Challenge Social Innovation. Potential for business, social entrepreneurship, welfare and civil society. Berlin: Springer, 241-259.

Totterdill, P., Dhondt S. \& Milsome S. (2002), Partners at work? A report to Europe's policy makers and social partners. Nottingham: The Work Institute.

Totterdill P., Pot F., Dhondt S. (2016), "Definiowanie innowacji w miejscu pracy," in Strumińska-Kutra M.; Rok B. (eds) Innowacje w miejscu pracy. Pomiędzy efektywnościa a jakościa życia społecznego, pp 25-50, Warszawa: Poltext.

Valkokari K., Paasi J. \& Rantala T. (2012), "Managing knowledge within networked innovation." Knowl Manage Res Pract 10: 27.

Vroom V. H. \& Yetton P. W. (1988), The New Leadership: Managing Participation in Organizations. Englewood Cliffs, NJ, Prentice Hall.

West M. (2012), Effective Teamwork: Practical Lessons from Organizational Research. Oxford: Blackwell.

Wood S. (1999), “Human Resource Management and Performance”. International Journal of Management Review, I (4). 